\title{
Thyroid-Stimulating Hormone
}

National Cancer Institute

\section{Source}

National Cancer Institute. Thyroid-Stimulating Hormone. NCI Thesaurus. Code C2280.

A peptide hormone secreted by the anterior pituitary. It promotes the growth of the

thyroid gland and stimulates the synthesis of thyroid hormones and the release of thyroxine by the thyroid gland. 